\title{
ANALISIS ALOKASI PENGELUARAN DAN TINGKAT KESEJAHTERAAN KELUARGA (STUDI DI KECAMATAN MEDAN KOTA, SUMATERA UTARA)
}

The Analysis of Family Expenditure Allocation and Welfare (A Study at the Sub-District of Medan City, North Sumatera)

$$
\text { Armaini Rambe }{ }^{1}, \text { Hartoyo }^{2} \text {, dan Emmy S Karsin }{ }^{3}
$$

\begin{abstract}
In recent years, issues on family welfare are being discussed. One aspect is concerning family welfare indicator and measurement. There are three measures of family welfare, i.e., BKKBN, BPS, and subjective measures. In general, this research was aimed to determine expenditure allocation and family welfare status, and to compare three measurements of welfare status. Cross sectional design and survey method were applied for this research. District of Medan Municipality, with Sudirejo I Sub District, Medan, North Sumatera were chosen purposively as study area. In this sub district 2 areas were chosen at random and 100 families were selected as samples and drawn using Proportional Stratified Random sampling method. Data of family demographic and socioeconomics characteristic, food and non food expenditure, and subjective perception of family welfare were collected for 2 months from Augusts to September 2003. Mann-Whitney test, Chi square, multiple regression, sensitivity and specificity, logistic regression was used to analyze data. The result indicates that the average of non food expenditure of the relatively wealthy family was six times higher than poor family. There was a significant difference of the proportion of food and non food expenditure between poor and wealthy family. Education and income influenced significantly family expenditure. Using BPS criteria as gold standard, the three poverty/welfare indicators (BKKBN, food expenditure and subjective perception) had high sensitivity as many as 100.0. BKKBN and food expenditure criteria were the highest specificity as many as $63.3 \%$ and the lowest was subjective perception criteria (22.4\%). The welfare determinant based on BPS criteria was the education of family head. The welfare determinant based on $B K K B N$ criteria was family income. The welfare determinant based on food expenditure was the number of family members and income. The welfare determinants based on subjective perception were the education of family head, the age of family head, the perception of price and income. The poverty threshold as much as $R p 230,000.00$ based on food expenditure considered the best and was chosen because it could classify poor family more than BKKBN criteria, and the education of family head with less than 13 years (the same as Senior High School level) also represented poverty indicator.
\end{abstract}

Key Words: family, expenditure, welfare, poverty

\section{PENDAHULUAN}

Kesejahteraan adalah suatu tata kehidupan dan penghidupan sosial, material, maupun spiritual yang diliputi rasa keselamatan, kesusilaan dan ketenteraman lahir batin yang memungkinkan setiap warganegara untuk mengadakan usaha-usaha pemenuhan kebutuhan jasmani, rohani dan sosial yang sebaik-baiknya bagi diri, keluarga serta masyarakat dengan menjunjung tinggi hak-hak asasi serta kewajiban manusia sesuai dengan Pancasila dan UUD 1945.
Turunnya pendapatan riil sangat dirasakan oleh semua lapisan masyarakat terutama yang berpenghasilan rendah dan menengah. Pada masyarakat berpenghasilan rendah, pendapatan yang mereka peroleh hanya cukup untuk memenuhi kebutuhan dasar (basic need), bahkan kebanyakan mereka sudah tidak mampu lagi memenuhi kebutuhan hidup secara layak, sehingga kualitas hidup keluarga dirasakan semakin menurun dan hal ini berdampak negatif 
terhadap tingkat kesejahteraan masyarakat. Namun demikian, tidak semua kemiskinan identik dengan ketidaksejahteraan, demikian juga dengan tingkat pendapatan yang tinggi belum mencerminkan tingkat kesejahteraan yang tinggi pula (Subagio et al. 2001).

Salah satu indikator kesejahteraan keluarga adalah dengan mengukur besarnya pengeluaran. Keluarga dengan kesejahteraan lebih baik, mempunyai persentase pengeluaran pangan lebih kecil dibanding keluarga dengan kesejahteraan lebih rendah. Jika dikaitkan dengan teori kebutuhan, maka pangan merupakan kebutuhan paling utama.

Dengan semakin kompleksnya permasalahan taraf kesejahteraan rakyat, maka informasi yang tepat dan pengukuran yang akurat sangat dibutuhkan untuk memperoleh alat ukur yang sesuai dengan kondisi daerah. Berbagai lembaga mengukur taraf kesejahteraan hanya berupa aspek yang dapat diamati dan dapat diukur. Seperti Badan Pusat Statisik misalnya, kesejahteraan rakyat menggunakan batas garis kemiskinan didasarkan pada data konsumsi dan pengeluaran pangan dan non pangan. Pada umumnya keluarga berpendapatan rendah di Indonesia membelanjakan sekitar $60-80 \%$ dari total pendapatannya untuk memenuhi kebutuhan pangan (Sukirman 1991).

Sementara BKKBN mempunyai kriteria khusus dan telah mengklasifikasikan keluarga sejahtera ke dalam lima kategori, yaitu keluarga: (1) Pra Sejahtera; (2) Sejahtera I; (3) Sejahtera II; (4) Sejahtera III; dan (5) Sejahtera III plus. Kesejahteraan yang subjektif juga dapat diperoleh dengan menanyakan langsung pada keluarga bagaimana pendapat/ persepsi kesejahteraan yang merupakan kenyataan dan diperoleh melalui pengalaman hidup sehari-hari dalam hubungannya dengan lingkungan (keluarga, kelompok dan masyarakat) untuk mencapai kesejahteraan hidup.

Tujuan penelitian ini adalah untuk:

(1) Mengidentifikasi karakteristik demografi, sosial-ekonomi, dan faktor eksternal keluarga miskin dan tidak miskin; (2) Mengetahui alokasi pengeluaran pangan dan non pangan keluarga miskin dan tidak miskin; (3) Menganalisis faktor-faktor yang mempengaruhi pengeluaran pangan dan non pangan keluarga; (4) Mengetahui tingkat kesejahteraan keluarga dengan berbagai metode pengukuran; (5) Mengetahui akurasi berbagai metoda pengukuran tingkat kesejahteraan keluarga; dan (6) Menganalisis faktor-faktor yang mempengaruhi tingkat kesejahteraan keluarga.

Manfaat

Memberi informasi bagi Pemerintah Daerah Sumatera Utara dalam menentukan kebijakankebijakan yang berhubungan dengan peningkatan kesejahteraan keluarga.

\section{METODE PENELITIAN}

Disain, Lokasi dan Waktu Penelitian

Disain penelitian ini adalah cross sectional. Penelitian dilakukan di Kecamatan Medan Kota, Kelurahan Sudirejo I Medan, Sumatera Utara. Pelaksanaan pengambilan data dilakukan selama 2 bulan, dari bulan Agustus - September 2003.

\section{Teknik Penarikan Contoh}

Contoh penelitian adalah keluarga yang menetap di Kecamatan Medan Kota. Kecamatan tersebut dipilih secara purposive dengan pertimbangan bahwa wilayah ini heterogen ditinjau dari aspek penduduk dalam suku, agama, dan mata pencaharian. Kelurahan Sudirejo I dipilih sebagai lokasi penelitian secara purposive berdasarkan jumlah kepala keluarga yang besar pada beberapa kategori tingkat keluarga sejahtera menurut BKKBN. Selanjutnya dari 12 
lingkungan yang terdapat pada kelurahan Sudirejo I dipilih 2 lingkungan secara acak sederhana (Simple Random Sampling). Jumlah contoh yang terpilih adalah 100 ibu keluarga yang ditetapkan secara purposive. Penarikan contoh dilakukan secara proporsional (Proportional Stratified Random Sampling). Klasifikasi kesejahteraan keluarga yang diperoleh dari kader, ternyata berbeda dengan yang ditemukan di lapang, sehingga peneliti menentukan contoh keluarga berdasarkan fakta yang ada di lapang.

\section{Teknik Pengumpulan Data}

Data yang dikumpulkan dalam penelitian ini terdiri dari data primer dan data sekunder. Data primer diperoleh dari wawancara terstruktur dengan menggunakan daftar pertanyaan (kuesioner), wawancara bebas dengan contoh tentang persepsi mereka tentang kesejahteraan.

Data sekunder meliputi tingkat kesejahteraan menurut kriteria BKKBN melalui Rekapitulasi Hasil Pendataan Keluarga Tingkat Dusun/ Lingkungan tahun 2002 yang dicatat oleh Petugas Lapangan Keluarga Berencana (PLKB). Data penunjang lainnya diperoleh melalui telaah dokumentasi dan kepustakaan dari publikasi/ laporan instansi terkait seperti BPS, BKKBN dan Pemerintah Kota Medan, Kantor Kecamatan, monografi desa dan lain-lain.

\section{Pengolahan dan Analisis Data}

Pengolahan data dilakukan menggunakan program SPSS 10.0 for Window. Analisis data penelitian ini dilakukan dengan : (1) Uji beda MannWhitney (mengetahui karakteristik demografi dan sosial ekonomi, serta perbedaan alokasi pengeluaran pangan dan non pangan RT); (2) Khi kuadrat (mengidentifikasi hubungan indikator BKKBN, pengeluaran pangan dan subjektif dengan kriteria BPS; (3) Analisis regresi berganda (menganalisis faktor-faktor apa yang berpengaruh terhadap pengeluaran RT); (4) Sensitifitas dan Spesifisitas (mengetahui akurasi berbagai metoda untuk mengukur tingkat kesejahteraan); dan (5) Analisis regresi logistik (menentukan cut off determinan tingkat kesejahteraan RT).

\section{HASIL DAN PEMBAHASAN}

Karakteristik Sosial Ekonomi Keluarga Usia. Rata-rata usia kepala keluarga contoh adalah 47.6 tahun, dimana rata-rata keluarga tidak miskin berusia lebih tua (49.2 tahun) dibandingkan keluarga miskin (44.9 tahun). Rata-rata usia responden istri adalah 43.5 tahun, dimana rata-rata usia responden pada keluarga tidak miskin lebih tua (44.6 tahun) dibandingkan keluarga miskin (41.6 tahun)

Jumlah Anggota Keluarga. Sebagian besar keluarga dalam penelitian termasuk keluarga sedang (berkisar antara 5-7 orang) yakni 76.3\% pada keluarga miskin dan $66.1 \%$ pada keluarga tidak miskin. Rata-rata jumlah anggota keluarga miskin dan tidak miskin tidak jauh berbeda, yakni berturut-turut $6.3 \pm 2.3$ orang dan $6.4 \pm 1.7$ orang. Tidak ada perbedaan yang nyata $(p>0.05)$ jumlah anggota keluarga miskin dan tidak miskin.

Pendidikan. Rata-rata lama pendidikan kepala keluarga tidak miskin lebih tinggi dibandingkan keluarga miskin, yakni berturut-turut 14.5 tahun dan 9.7 tahun. Sementara rata-rata lama pendidikan responden pada keluarga tidak miskin (13.6 tahun) lebih tinggi dibandingkan keluarga miskin (8.1 tahun). Terdapat perbedaan yang nyata $(p<0.05)$ antara pendidikan kepala keluarga miskin dan tidak miskin.

Pekerjaan. Sebagian besar kepala keluarga pada keluarga tidak miskin mempunyai pekerjaan sebagai PNS/ABRI yakni sebesar $30.6 \%$. Sementara itu, pada keluarga miskin yang paling banyak adalah kepala 
keluarga dengan mata pencaharian sebagai supir (26.3\%). Responden/istri pada keluarga tidak miskin lebih banyak yang berprofesi sebagai PNS yakni $30.6 \%$, sedangkan pada keluarga miskin sebagian besar responden (31.6\%) adalah ibu keluarga.

Pendapatan. Rata-rata pendapatan rumah-tangga tidak miskin lebih tinggi yakni Rp $\quad 832,609.10 \pm 740,858.40$ dibandingkan keluarga miskin yakni Rp 151,326.50 \pm 59,424.10. Hasil uji beda Mann-Whitney menunjukkan adanya perbedaan yang nyata $(p<0.05)$ pendapatan keluarga miskin dan tidak miskin.

Aset. Ditinjau dari kepemilikan aset, keluarga tidak miskin mempunyai aset yang lebih banyak dibandingkan keluarga miskin.

Agama. Persentase keluarga miskin yang beragama Islam adalah $71.1 \%$ dan keluarga tidak miskin adalah $74.2 \%$.

Etnis. Sebagian besar responden berasal dari etnis Batak, Melayu dan Minang yang lebih cenderung memilih pasangan hidup dari etnis yang sama. Sementara itu, responden dari etnis Jawa memilih pasangan dari beragam etnis.

\section{Faktor Eksternal}

Persepsi Harga. Dari segi harga yang menggambarkan daya beli keluarga, sebagian besar responden menganggap bahwa mereka belum sejahtera karena harga-harga barang, baik pangan maupun non pangan masih sulit untuk dijangkau. Sebanyak $97.4 \%$ keluarga miskin dan $82.3 \%$ rumah tangga tidak miskin menganggap harga-harga saat ini tidak mensejahterakan mereka.

Persepsi Tempat Tinggal. Sebagian besar (62.9\%) keluarga tidak miskin menganggap tempat tinggalnya sudah memadai dan dapat mensejahterakan mereka. Sebaliknya, sebagian besar (76.3\%) keluarga miskin merasa belum sejahtera dari segi kondisi tempat tinggalnya.

Persepsi Agama. Persepsi kesejahteraan dari segi agama menunjukkan bahwa sebagian besar responden baik pada keluarga miskin maupun tidak miskin mengaku belum sejahtera yakni berturut-turut 92.1 dan $71.0 \%$

Persepsi Budaya. Sebanyak $81.6 \%$ keluarga miskin mempunyai persepsi tidak sejahtera dari segi budaya. Sebaliknya, separuh (51.6\%) keluarga tidak miskin menganggap sudah sejahtera dari segi budaya.

Secara umum persepsi subjektif responden terhadap kesejahteraannya lebih tinggi pada keluarga tidak miskin (66.5 \pm 15.2$)$ dibandingkan keluarga miskin (36.7 \pm 10.2$)$.

\section{Alokasi Pengeluaran}

Rata-rata pengeluaran pangan keluarga tidak miskin lebih besar dibandingkan keluarga miskin, yakni berturut-turut $\mathrm{Rp} 229,810.20$ dan Rp 126,112.40 (Tabel 1). Komponen pengeluaran pangan terbesar pada kedua kelompok adalah untuk ikan. Semakin tinggi tingkat pendapatan keluarga, pengeluaran untuk pangan hewani akan semakin meningkat. Namun karena harga ikan yang relatif terjangkau di Kota Medan, membuat keluarga miskin juga mampu mengkonsumsi ikan sehari-hari. Sumber pangan hewani lainnya yang sering dikonsumsi oleh keluarga tidak miskin adalah daging. Hasil Susenas (1986) menunjukkan bahwa kelompok ikan sebagai sumber utama makanan yang mengandung protein lebih disukai penduduk luar Jawa dibandingkan penduduk Jawa.

Hal yang menarik dalam pengeluaran pangan ini adalah komponen pengeluaran kedua terbesar pada keluarga miskin adalah untuk tembakau dan sirih. Sementara pada keluarga tidak miskin komponen pengeluaran pangan kedua terbanyak adalah untuk makanan dan minuman 
yang termasuk didalamnya untuk jajan atau makan di luar rumah. Secara umum, pada semua komponen pengeluaran pangan, kecuali untuk komponen minuman mengandung alkohol dan tembakau dan sirih, pengeluaran keluarga tidak miskin lebih tinggi dibandingkan keluarga miskin.

Hasil uji beda Mann-Whitney menunjukkan bahwa pada sebagian besar komponen pengeluaran pangan kecuali umbi-umbian, kacangkacangan, minuman mengandung alcohol, serta tembakau dan sirih berbeda nyata $(p<0.05)$ antara keluarga miskin dan tidak miskin. Total pengeluaran pangan antara keluarga miskin dan tidak miskin juga menunjukkan perbedaan yang nyata $(p<0.05)$.

Tabel 1. Deskripsi Komponen Pengeluaran Pangan dan Non Pangan berdasarkan Status Kesejahteraan

\begin{tabular}{|c|c|c|c|c|c|c|}
\hline \multirow{2}{*}{$\begin{array}{c}\text { Pengeluaran } \\
\text { Pangan } \\
\text { dan Non Pangan }\end{array}$} & \multicolumn{2}{|c|}{ Miskin $(n=38)$} & \multicolumn{2}{|c|}{ Tidak Miskin $(n=62)$} & \multicolumn{2}{|c|}{ Total $(n=100)$} \\
\hline & $\begin{array}{l}\text { Rata- } \\
\text { Rata }\end{array}$ & SD & $\begin{array}{l}\text { Rata- } \\
\text { Rata }\end{array}$ & SD & Rata-Rata & SD \\
\hline 1. Padi-padian & 19.984 .9 & 6.620 .4 & 23.427 .5 & 7.655 .4 & $22.119 .3^{\mathrm{bn}}$ & 7.437 .2 \\
\hline 2. Umbi-umbian & 429.4 & 608.6 & 406.0 & 830.9 & $414.9^{\text {tn }}$ & 751.0 \\
\hline 3. Ikan & 22.687 .2 & 7.785 .7 & 47.124 .6 & 29.906 .8 & $37.838 .4^{\mathrm{bn}}$ & 26.755 .9 \\
\hline 4. Daging & 5.325 .9 & 4.732 .6 & 22.660 .7 & 14.815 .0 & $16.073 .5^{\mathrm{bn}}$ & 14.667 .0 \\
\hline 5. Telur dan Susu & 10.062 .6 & 6.923 .6 & 16.903 .8 & 14.337 .9 & $14.304 .2^{\mathrm{bn}}$ & 12.478 .8 \\
\hline 6. Sayur-sayuran & 9.291 .0 & 3.632 .1 & 12.275 .4 & 5.792 .6 & $11.141 .3^{\mathrm{bn}}$ & 5.265 .4 \\
\hline 7. Kacang-kacangan & 4.101 .0 & 3.050 .9 & 4.964 .5 & 3.324 .8 & $4.636 .4^{9 t \mathrm{tn}}$ & 3.235 .3 \\
\hline 8. Buah-buahan & 5.313 .2 & 4.581 .7 & 21.222 .1 & 17.348 .5 & $15.176 .7^{\mathrm{bn}}$ & 15.922 .4 \\
\hline 9. Minyak dan Lemak & 4.905 .9 & 2.127 .1 & 7.465 .5 & 4.440 .6 & $6.492 .9^{\mathrm{bn}}$ & 3.924 .3 \\
\hline 10. Bahan minuman & 5.254 .0 & 2.547 .3 & 9.481 .5 & 4.373 .3 & $7.875 .1^{\mathrm{bn}}$ & 4.296 .8 \\
\hline 11. Bumbu-bumbuan & 1.471 .6 & 664.0 & 2.781 .2 & 1.381 .9 & $2.283 .6^{b n}$ & 1.322 .7 \\
\hline 12. Konsumsi lainnya & 4.274 .7 & 3.273 .9 & 7.446 .5 & 4.497 .1 & $6.241 .2^{b n}$ & 4.343 .0 \\
\hline $\begin{array}{l}\text { 13. Makanan dan } \\
\text { Minuman }\end{array}$ & 11.845 .4 & 10.573 .1 & 32.011 .9 & 26.115 .6 & $24.348 .6^{\mathrm{bn}}$ & 23.639 .0 \\
\hline $\begin{array}{l}\text { 14. Minuman } \\
\text { mengandung } \\
\text { alkohol }\end{array}$ & 449.9 & 1.612 .8 & 420.7 & 2.078 .5 & $431.8^{9 t n}$ & 1.906 .4 \\
\hline 15. Tembakau \& sirih & 20.715 .7 & 16.964 .5 & 21.218 .3 & 26.703 .4 & $21.027 .3^{9 t n}$ & 23.387 .8 \\
\hline Pengeluaran Pangan & 126.112 .4 & 32.288 .4 & 229.810 .2 & 89.020 .0 & $190.405 .1^{b n}$ & 88.495 .8 \\
\hline $\begin{array}{ll}\text { 1. } & \text { Perumahan } \quad \& \\
\text { Fasilitas RT }\end{array}$ & 41.620 .0 & 26.223 .3 & 215.726 .9 & 159.541 .7 & $149.566 .3^{\mathrm{bn}}$ & 152.165 .8 \\
\hline $\begin{array}{l}\text { 2. Aneka barang dan } \\
\text { jasa }\end{array}$ & 12.060 .9 & 8.816 .6 & 135.760 .2 & 158.807 .2 & $88.754 .5^{b n}$ & 138.599 .9 \\
\hline 3. Pendidikan & 22.654 .5 & 17.776 .4 & 94.737 .9 & 115.830 .9 & $67.346 .2^{\mathrm{bn}}$ & 98.089 .5 \\
\hline 4. Kesehatan & 11.856 .5 & 20.038 .3 & 23.888 .2 & 57.175 .5 & $19.316 .2^{9 \mathrm{tn}}$ & 46.891 .1 \\
\hline $\begin{array}{l}\text { 5. Pakaian, alas kaki } \\
\text { dan tutup kepala }\end{array}$ & 8.512 .3 & 5.268 .8 & 45.537 .3 & 33.887 .4 & $31.467 .8^{\mathrm{bn}}$ & 32.313 .8 \\
\hline 6. Barang tahan lama & 5.170 .2 & 29.697 .2 & 54.080 .9 & 139.768 .4 & $35.494 .8^{\mathrm{bn}}$ & 113.735 .5 \\
\hline 7. Pajak dan asuransi & 666.8 & 1.139 .6 & 20.223 .5 & 49.204 .6 & $12.791 .9^{\mathrm{bn}}$ & 39.790 .6 \\
\hline $\begin{array}{lll}\text { 8. } & \begin{array}{l}\text { Keperluan } \\
\text { dan upacara }\end{array} & \text { pesta } \\
\end{array}$ & 1.384 .2 & 3.120 .2 & 18.745 .6 & 73.035 .0 & $12.148 .3^{b n}$ & 57.983 .2 \\
\hline $\begin{array}{ll}\text { Pengeluaran } & \text { Non } \\
\text { Makanan } & \\
\end{array}$ & 103.925 .4 & 53.734 .6 & 608.700 .5 & 472.050 .4 & $416.886 .0^{b n}$ & 446.112 .3 \\
\hline Total Pengeluaran & 230.037 .8 & 70.920 .5 & 838.510 .8 & 530.035 .7 & 607.291.0 ${ }^{\text {bn }}$ & 512.925 .3 \\
\hline
\end{tabular}

Ket : bn= berbeda nyata $(p<0.05)$ antara keluarga miskin dan tidak miskin tn=tidak berbeda nyata $(p>0.05)$ antara keluarga miskin dan tidak miskin 
Secara umum rata-rata pengeluaran non pangan keluarga tidak miskin enam kali lebih besar (Rp 608,700.50) dibandingkan kelompok keluarga miskin (Rp 103,925.40). Komponen pengeluaran terbesar pada keluarga miskin dan tidak miskin adalah untuk perumahan dan fasilitas keluarga. Sementara itu, komponen pengeluaran terkecil pada keluarga miskin adalah untuk pajak dan asuransi, sedangkan pada keluarga tidak miskin untuk keperluan pesta dan upacara.

Pengeluaran keluarga tidak miskin pada semua komponen non pangan, lebih tinggi dibandingkan pengeluaran keluarga miskin. Pengeluaran keluarga tidak miskin pada semua komponen non pangan, lebih tinggi dibandingkan pengeluaran keluarga tidak miskin. Rata-rata pengeluaran total yang merupakan penjumlahan pengeluaran pangan dan non pangan keluarga tidak miskin lebih besar dibandingkan keluarga miskin yakni berturut-turut Rp 838,510.80 dan Rp 230,037.80 (Tabel 1).

Persentase pengeluaran pangan pada keluarga miskin (56.4\%) lebih besar dibandingkan pengeluaran non pangan (43.6\%). Sebaliknya, pada keluarga tidak miskin, persentase pengeluaran pangan (33.6\%) lebih rendah dibandingkan pengeluaran non pangan (66.4\%) (Tabel 2).

Hasil uji statistik menunjukkan adanya perbedaan yang nyata $(p<0.05)$ persentase pengeluaran pangan dan non pangan di antara keluarga miskin dan tidak miskin. Jika dibandingkan dengan BPS (2002) dimana persentase pengeluaran ratarata per kapita per bulan di wilayah perkotaan Sumatera Utara untuk pangan adalah $65.5 \%$ dan $31.7 \%$ untuk konsumsi bukan pangan, maka kesejahteraan keluarga contoh dalam penelitian ini sudah lebih baik.

Tabel 2. Persentase Pengeluaran Pangan dan Non Pangan terhadap Pengeluaran Total berdasarkan Status Kesejahteraan

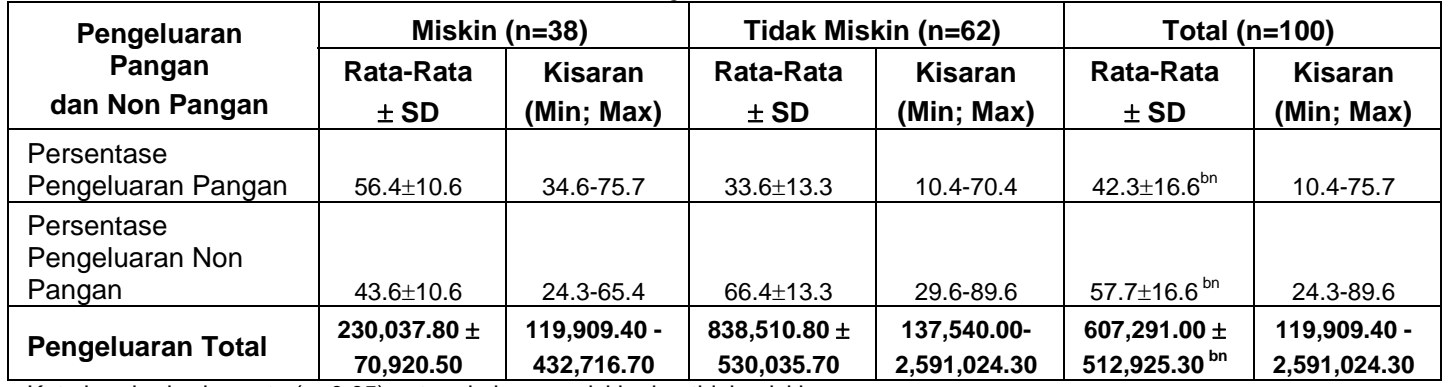

Ket : bn= berbeda nyata $(p<0.05)$ antara keluarga miskin dan tidak miskin

\section{Faktor-Faktor yang Mempengaruhi} Pengeluaran Keluarga

Hasil analisis regresi berganda menunjukkan bahwa dari 5 peubah karakteristik sosial ekonomi dan persepsi, ternyata hanya pendidikan dan pendapatan yang berpengaruh nyata $(p<0.05)$ terhadap pengeluaran keluarga (Tabel 3). Pengaruh faktor demografi, sosial ekonomi dan faktor eksternal terhadap pengeluaran keluarga adalah sebesar $74.9 \%$.
Hasil penelitian Megawangi et al. (1994) membuktikan bahwa tingkat pendapatan dan pendidikan suami berhubungan nyata dan positif terhadap kebiasaan merencanakan anggaran biaya. Studi kuantitatif tentang anggaran/pengeluaran keluarga pertama kali dilaksanakan oleh Engel, hasil studi empirisnya adalah: (1) kategori/proporsi terbesar dari anggaran keluarga adalah untuk makanan, (2) proporsi pengeluaran total untuk makanan menurun dengan 
meningkatnya pendapatan, proporsi pengeluaran total untuk pakaian dan perumahan diperkirakan konstan, sementara proporsi pengeluaran untuk barang-barang mewah bertambah ketika pendapatan mulai meningkat. Dari ketiga hasil temuan di atas, temuan kedualah yang secara umum berlaku dewasa ini. Teori Engel ini sangat penting untuk mempelajari tingkat kesejahteraan ekonomi suatu masyarakat, atau untuk menganalisis perilaku konsumsi makanan dan bukan makanan sebuah keluarga.

Tabel 3. Faktor-Faktor yang Mempengaruhi Pengeluaran Keluarga

\begin{tabular}{|l|r|r|r|l|}
\hline \multicolumn{1}{|c|}{ Peubah Bebas } & \multicolumn{1}{c|}{ B } & \multicolumn{1}{c|}{ Galat } & \multicolumn{1}{c|}{ Beta-Std } & \multicolumn{1}{c|}{ Sig } \\
\hline Konstanta & -248.633 & & -1.442 & 0.153 \\
\hline Pendidikan KK & $\mathbf{1 6 . 3 3 6}$ & $\mathbf{0 . 1 3 5}$ & $\mathbf{2 . 1 3 8}$ & $\mathbf{0 . 0 3 5}$ \\
\hline Jumlah anggota rumah tangga & 20.093 & 0.076 & 1.479 & 0.142 \\
\hline Umur Kepala RT & 2.375 & 0.039 & 0.755 & 0.452 \\
\hline Pendapatan & $\mathbf{0 . 5 7 2}$ & $\mathbf{0 . 7 4 8}$ & $\mathbf{1 3 . 0 0 1}$ & $\mathbf{0 . 0 0 0}$ \\
\hline Persepsi harga & 115.324 & 0.105 & 1.657 & 0.101 \\
\hline
\end{tabular}

Ket : Adjusted $R$ Square $=0.749$

Suhardjo (1989) mengemukakan bahwa pendapatan sangat berpengaruh terhadap alokasi pengeluaran keluarga. Keluarga berpenghasilan rendah akan menggunakan sebagian besar pendapatannya untuk pangan sebagai kebutuhan pokok. Pendidikan dan pekerjaan mempengaruhi selera dan preferensi konsumen pada jenis dan tingkat pengeluaran pilihan (Fan 1997; Ghany \& Sharpe 1997). Tingkat pendapatan yang tinggi memberi peluang lebih besar bagi keluarga untuk memilih pangan yang baik berdasarkan jumlah maupun jenisnya (Roedjito 1989). Rendahnya pendapatan merupakan rintangan yang menyebabkan orang tak mampu membeli pangan dalam jumlah yang diperlukan (Sajogyo et al. 1994).

\section{Pengukuran Tingkat Kesejahteraan}

Besar angka kemiskinan dan cara menghitungnya menjadi bahan diskusi aktual akibat perbedaan dalam cara yang digunakan. Penghitungan keluarga miskin di Indonesia telah dicoba dikembangkan pada tingkat nasional. Indikator kemiskinan sangat dibutuhkan oleh pemerintah maupun lembaga non pemerintah untuk menentukan keluarga yang menjadi kelompok sasaran program-program pengentasan kemiskinan. Beberapa indikator kemiskinan yang dijadikan acuan penentuan keluarga miskin adalah kriteria BKKBN, BPS, pengeluaran pangan dan persepsi subjektif.

Kesejahteraan menurut BKKBN. Sebanyak $38.0 \%$ keluarga contoh tergolong miskin menurut kriteria BKKBN, sementara sisanya yakni $62.0 \%$ tergolong tidak miskin (Gambar 1). Dalam konsep BKKBN, keluarga dikategorikan menjadi 5 (lima) yaitu keluarga pra sejahtera, keluarga sejahtera I, keluarga sejahtera II, keluarga sejahtera III, dan keluarga sejahtera III plus. Keluarga miskin adalah keluarga pra sejahtera dan keluarga sejahtera I sedangkan keluarga sejahtera II, III dan III plus masuk kategori bukan keluarga miskin.

Beberapa kelemahan penentuan kesejahteraan BBKBN Banyaknya data dan informasi yang harus dikumpulkan membutuhkan tingkat pemahaman yang tinggi, padahal tidak setiap kader mampu menguasai permasalahan, karena diantara mereka memiliki kemampuan yang berbeda-beda; (2) Sistem nepotisme yang mengedepankan kekeluargaan membuat kader seringkali mengurangi atau 
menambah data sesuai program yang akan dilakukan, misalnya program JPS, raskin, beasiswa dan pelayanan pengobatan gratis; (3) Inkonsistensi variabel indikator, misalnya untuk Kota Medan variabel lantai sebagian besar tanah tidak digunakan, tapi lebih cenderung menggunakan luas lantai rumah untuk menentukan tingkat kesejahteraan; (4) Variabel melaksanakan ibadah agama sangat subjektif dan sulit dinilai tingkat kesejahteraannya; dan (5) Variabel minimum dalam seminggu mengkonsumsi pangan hewani (daging, ikan, telur) bila ditinjau dari segi harga tidak mempunyai elastisitas yang sama, dimana harga daging jauh di atas harga telur yang mampu dikonsumsi hampir semua keluarga.

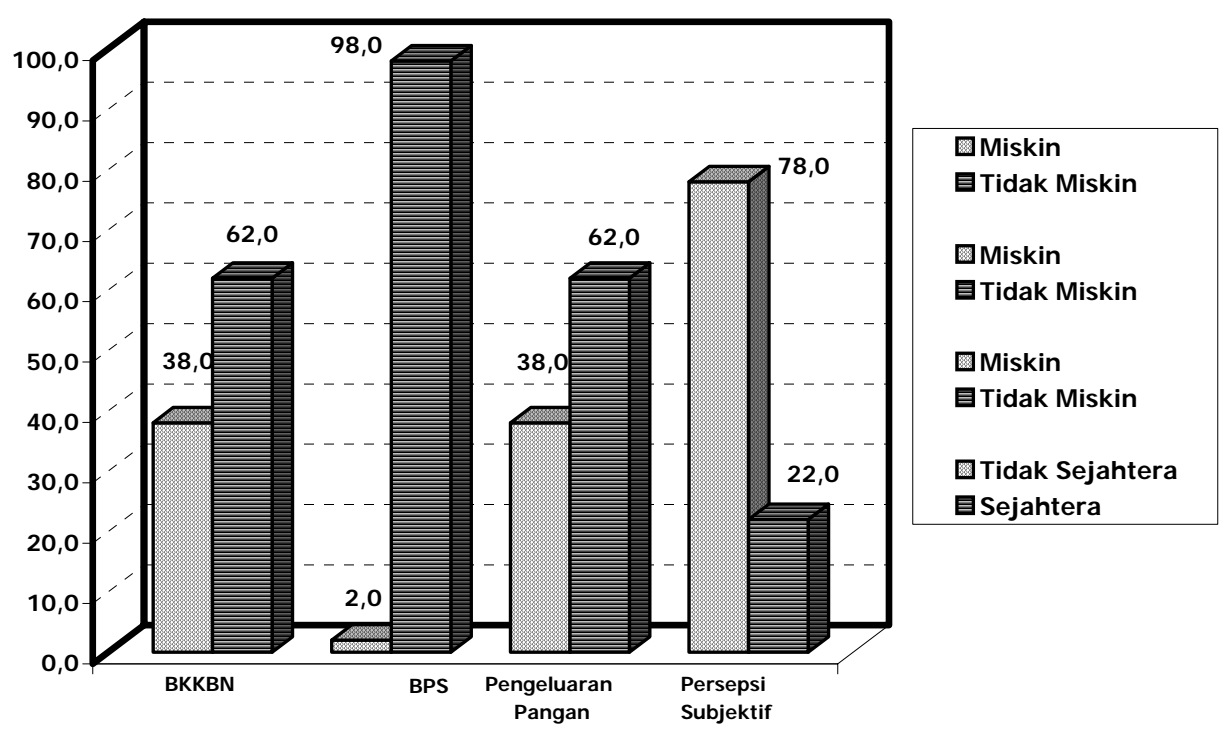

Gambar 1. Sebaran Keluarga berdasarkan Kriteria Kemiskinan BPS, BKKBN, Pengeluaran Pangan dan Persepsi Subjektif

Kelebihan indikator BKKBN adalah tidak memberikan ukuran yang lebih langsung tentang keluarga miskin pada tingkat nasional dan tingkat administratif yang lebih rendah (desa) dan pada tingkat keluarga. Data tersebut dikumpulkan secara rutin melalui pendaftaran keluarga dengan menggunakan indikatorindikator ekonomi dan non ekonomi.

Kesejahteraan menurut Badan Pusat Statistik (BPS). Indikator kemiskinan BPS mengklasifikasikan keluarga miskin sebesar $2.0 \%$. Sisanya (98.0\%) masuk dalam kategori tidak miskin (Gambar 1). Rendahnya persentase keluarga miskin BPS disebabkan terlalu rendahnya garis kemiskinan yang digunakan. Jika dibandingkan dengan pendapatan, seringkali pengeluaran keluarga jauh lebih tinggi, sehingga garis kemiskinan berada jauh di bawah pengeluaran.

Beberapa kelemahan indikator BPS adalah : (1) Teknik sampling sensus blok untuk daerah perkotaan yang dilakukan Susenas bersifat umum dan tidak mampu mewakili seluruh keluarga. Selain itu BPS belum mengaitkan keberadaan sarana dan prasarana wilayah dengan jumlah penduduk, sehingga sejauhmana keberadaan prasarana tersebut dapat menjangkau penduduk tidak tergambar (Rusli, et al. 1995); (2) 
Waktu wawancara yang lama, daya ingat responden, lemahnya stratifikasi dan keengganan responden untuk menjawab dengan benar menghambat tercapainya mutu data yang diharapkan; dan (3) Beberapa peubah yang ditanyakan pada responden tidak mencerminkan pengeluaran riil keluarga, misalnya keluarga yang memiliki rumah sendiri harus diestimasi nilainya dan dianggap sebagai pengeluaran. Kelebihan BPS adalah mudah dilakukan secara manual oleh pihak daerah, bahkan dengan menggunakan alat analisis statistik yang sederhana seperti penjumlahan skor pun sudah dapat dilakukan (Rusli, et al. 1995).

Kesejahteraan

menurut Pengeluaran Pangan. Indikator kemiskinan menurut pengeluaran pangan mengklasifikasikan $38.0 \%$ keluarga contoh ke dalam kategori miskin (Gambar 1). Sudah sejak lama makanan dijadikan sebagai indikator oleh ekonom untuk melihat tingkat kesejahteraan masyarakat. Teori Engel mengatakan bahwa semakin tinggi pendapatan seseorang atau keluarga, maka semakin kecil proporsi pendapatan yang dibelanjakan untuk makanan. Standar minimum kecukupan makanan yang diperlukan oleh individu ditentukan menurut perbedaan biologis dan kegiatan dalam satu kelompok demografi. Nilai rata-rata kebutuhan kalori per kapita menggambarkan rata-rata kebutuhan minimum biologis yang berbeda-beda berdasarkan kelompok penduduk tersebut (Mathur 1995; Quibria 1991). Pengukuran kemiskinan berdasarkan pengeluaran pangan tidak bisa menggambarkan dimensi kesejahteraan, misalnya aspek kesehatan, harapan hidup, dll.

Kesejahteraan berdasarkan Persepsi Subjektif. Penggolongan kesejahteraan berdasar-kan persepsi subjektif contoh terhadap kesejahteraan, diperoleh $\quad 78.0 \%$ keluarga termasuk kategori tidak sejahtera (Gambar 1). Pendekatan subyektif mendefinisikan kemiskinan berdasarkan pemahaman penduduk mengenai standar hidup mereka dan bagaimana mereka mengartikannya. Penduduk mungkin mempunyai pandangan sendiri tentang apa arti kemiskinan yang mungkin bisa berbeda dengan pandangan obyektif. Pendekatan subyektif pengukuran kemiskinan sulit digunakan dalam studi-studi makro, tetapi dapat memberikan pengertian yang mendalam tentang masalah kemiskinan di daerah-daerah dengan kondisi kebudayaan yang berbeda. Dengan demikian pendekatan tersebut tidak dapat digunakan pada tingkat nasional dan makro, sehingga hanya dianggap sebagai pelengkap untuk mengetahui secara mendalam mengenai keluarga miskin dan apa yang terjadi dalam kehidupan keluarga tersebut.

Beberapa indikator yang dihasilkan dari penggunaan pendekatan mikro-subyektif akan sangat membantu dalam mengembangkan program-program intervensi pada kelompok sasaran spesifik yang paling terpengaruh oleh krisis (Raharto \& Romdiati dalam WKNPG 2000).

Akurasi berbagai Metode Pengukuran Kesejahteraan

Uji sensitivitas dan spesifisitas dilakukan untuk menilai akurasi berbagai indikator yang digunakan. Sensitivitas adalah kemampuan untuk menemukan keluarga miskin, sedangkan spesifisitas adalah kemampuan untuk menemukan keluarga yang tidak miskin. Sebaran keluarga berdasarkan indikator kesejahteraan disajikan pada Tabel 4. Misklasifikasi (positif semu) kriteria BKKBN dan pengeluaran pangan tidak berbeda dalam mengkategorikan keluarga miskin yang ternyata menurut kriteria BPS tidak miskin, yang masing-masing adalah sebesar $36.7 \%$. Persentase 
misklasifikasi yang cukup tinggi terjadi pada kriteria persepsi subjektif yakni sebesar $77.6 \%$. Sementara itu, tidak terjadi misklafikasi (negatif semu) dari ketiga kriteria pada keluarga tidak miskin (Tabel 4).

Tabel 4. Sebaran Keluarga berdasarkan Indikator Kesejahteraan BKKBN, Pengeluaran Pangan dan Persepsi Subjektif sebagai Gold Standar BPS

\begin{tabular}{|c|c|c|c|c|c|c|c|}
\hline \multirow{3}{*}{$\begin{array}{l}\text { Indikator } \\
\text { Kemiskinan }\end{array}$} & \multirow{3}{*}{$\begin{array}{c}\text { Status } \\
\text { Kemiskinan/ } \\
\text { Kesejahteraan }\end{array}$} & \multicolumn{6}{|c|}{ Kriteria Kemiskinan BPS } \\
\hline & & \multicolumn{2}{|c|}{ Miskin $(n=2)$} & \multicolumn{2}{|c|}{ Tidak Miskin (n=98) } & \multicolumn{2}{|c|}{ Total $(n=100)$} \\
\hline & & $\mathbf{n}$ & $\%$ & $\mathbf{n}$ & $\%$ & $\mathbf{n}$ & $\%$ \\
\hline \multirow{3}{*}{ BKKBN } & Miskin & 2 & 100.0 & 37 & 37.8 & 39 & 39.0 \\
\hline & Tidak Miskin & 0 & 0.0 & 61 & 62.2 & 61 & 61.0 \\
\hline & Total & 2 & 100.0 & 98 & 100.0 & 100 & 100.0 \\
\hline \multirow{3}{*}{$\begin{array}{l}\text { Pengeluaran } \\
\text { Pangan }\end{array}$} & Miskin & 2 & 100.0 & 36 & 36.7 & 38 & 38.0 \\
\hline & Tidak Miskin & 0 & 0.0 & 62 & 63.3 & 62 & 62.0 \\
\hline & Total & 2 & 100.0 & 98 & 100.0 & 100 & 100.0 \\
\hline \multirow{3}{*}{$\begin{array}{l}\text { Persepsi } \\
\text { Subjektif }\end{array}$} & Tidak Sejahtera & 2 & 100.0 & 76 & 77.6 & 78 & 78.0 \\
\hline & Sejahtera & 0 & 0.0 & 22 & 22.4 & 22 & 22.0 \\
\hline & Total & 2 & 100.0 & 98 & 100.0 & 100 & 100.0 \\
\hline
\end{tabular}

Ketiga indikator kemiskinan/ kesejahteraan (BKKBN, pengeluaran pangan dan persepsi subjektif mempunyai sensitifitas yang tinggi yakni $100.0 \%$ jika digunakan kriteria BPS sebagai gold standard. Spesifisitas yang tertinggi dijumpai pada kriteria BKKBN dan pengeluaran pangan yakni $63.3 \%$, dan yang paling rendah adalah kriteria persepsi subjektif (22.4\%) (Tabel 5).

Hasil analisis khi kuadrat menunjukkan adanya korelasi yang nyata $(P<0.1)$ di antara kriteria kemiskinan BKKBN dan pengeluaran subjektif dengan kriteria BPS. Kriteria persepsi subjektif menunjukkan tidak adanya hubungan yang nyata $(p>0.05)$ dengan kriteria BPS.

Tabel 5. Sensitifitas dan Spesifisitas Indikator Kemiskinan BKKBN, Pengeluaran Pangan dan Persepsi Subjektif dengan Gold Standar Kriteria BPS

\begin{tabular}{|l|r|r|r|}
\hline \multicolumn{1}{|c|}{ Indikator Kemiskinan } & Sensitifitas & Spesifisitas & \multicolumn{1}{c|}{ Khi Kuadrat } \\
\hline BKKBN & 100.0 & 63.3 & $0.074^{\star}$ \\
\hline Pengeluaran Pangan & 100.0 & 63.3 & $0.068^{\star}$ \\
\hline Persepsi Subjektif & 100.0 & 22.4 & 0.448 \\
\hline
\end{tabular}

Ket : * nyata pada $\mathrm{p}<0.1$

Faktor-Faktor yang Mempengaruhi Tingkat Kesejahteraan Keluarga

Analisis regresi logistik dengan metode Backward: Wald digunakan terhadap 5 peubah sosial ekonomi, demografi dan persepsi keluarga untuk mengetahui determinan kesejahteraan. Determinan kriteria kesejahteraan BPS yang paling berpengaruh nyata $(p<0.1)$ adalah pendidikan kepala RT dengan nilai odd ratio sebesar 1.7, yang berarti peluang keluarga untuk sejahtera lebih tinggi 1.7 kali jika pendidikan kepala RT semakin tinggi atau setara perguruan tinggi (Tabel 6).

Peubah yang paling menentukan kesejahteraan menurut kriteria BKKBN adalah pendapatan keluarga yang pengaruhnya sangat nyata $(p<0.01)$ dengan nilai odd ratio sebesar 1.021. Angka ini mengindikasikan bahwa peluang keluarga untuk sejahtera adalah 1 kali lebih tinggi jika pendapatannya lebih tinggi dibandingkan keluarga dengan pendapatan rendah (Tabel 6). 
Tabel 6. Faktor-Faktor yang Mempengaruhi Kesejahteraan Keluarga

\begin{tabular}{|l|l|r|r|r|}
\hline \multicolumn{1}{|c|}{ Peubah Tak Bebas } & \multicolumn{1}{|c|}{ Peubah Bebas } & \multicolumn{1}{c|}{ B } & \multicolumn{1}{c|}{ Sig. } & \multicolumn{1}{c|}{ Odd Ratio } \\
\hline \multirow{2}{*}{ Kriteria BPS } & Pendidikan Kepala RT & 0.503 & 0.057 & 1.654 \\
\cline { 2 - 5 } & Konstanta & -0.505 & 0.771 & 0.604 \\
\hline \multirow{2}{*}{ Kriteria BKKBN } & Pendapatan & 0.021 & 0.000 & 1.021 \\
\cline { 2 - 5 } & Konstanta & -4.805 & 0.000 & 0.008 \\
\hline \multirow{2}{*}{$\begin{array}{l}\text { Kriteria menurut Pengeluaran } \\
\text { Pangan }\end{array}$} & Jumlah Anggota RT & 0.361 & 0.049 & 1.435 \\
\cline { 2 - 5 } & Pendapatan & 0.010 & 0.000 & 1.010 \\
\cline { 2 - 5 } & Konstanta & -4.933 & 0.000 & 0.007 \\
\hline \multirow{4}{*}{ Kriteria Persepsi Subjektif } & Pendidikan Kepala RT & 0.268 & 0.008 & 1.307 \\
\cline { 2 - 5 } & Umur Kepala RT & 0.076 & 0.044 & 1.079 \\
\cline { 2 - 5 } & Persepsi Harga & 0.026 & 0.052 & 1.026 \\
\cline { 2 - 5 } & Pendapatan & 0.001 & 0.031 & 1.001 \\
\cline { 2 - 5 } & Konstanta & -10.919 & 0.000 & 0.000 \\
\hline
\end{tabular}

Analisis logistik juga menunjukkan bahwa jumlah anggota RT dan pendapatan menjadi faktor determinan kriteria kesejahteraan menurut pengeluaran pangan (Tabel 6). Sementara itu, peubah-peubah yang secara nyata berpengaruh nyata terhadap kesejahteraan menurut persepsi subjektif adalah pendidikan kepala RT, umur kepala RT, persepsi harga dan pendapatan. Peubah yang mempunyai peluang paling tinggi diantara keempat peubah yang nyata tersebut adalah pendidikan kepala RT yang mempunyai nilai odd ratio sebesar 1.3. Angka ini mengindikasikan bahwa semakin tinggi tingkat pendidikan kepala RT maka keluarga berpeluang lebih besar untuk sejahtera.

Insiden kemiskinan sangat sensitif terhadap fluktuasi harga-harga komoditi dasar. Ketika harga-harga naik, garis kemiskinan juga naik sejalan dengan membumbungnya biaya yang harus dibayar golongan bawah untuk memenuhi standar minimum kebutuhan makanan dan bukan makanan.

Seiring dengan adanya perkembangan peradaban dan kebudayaan manusia, kemajuan ilmu dan teknologi, kebutuhan manusia itu terus meningkat sehingga selain kebutuhan dasar, manusia memiliki kebutuhan-kebutuhan tambahan yang sangat banyak macam dan ragamnya. Keragaman kebutuhan ini ditentukan oleh berbagai faktor, seperti faktor umur, pendidikan dll (Sugiarto, et al. 2000). Hasil penelitian Megawangi et al. (1994) membuktikan bahwa pendidikan kepala keluarga dan jumlah anggota keluarga berhubungan nyata berpengaruh terhadap kebiasaan merencanakan anggaran biaya.

Berdasarkan hasil analisis logistik ditemukan bahwa diantara ketiga kriteria kesejahteraan (BKKBN, pengeluaran pangan dan persepsi subjektif), pendapatan memberikan pengaruh yang nyata dan dipilih angka Rp 230,000.00 yang berada diantara cut off kriteria kesejahteraan BKKBN (Rp 228,000.00) dan kriteria kesejahteraan subjektif (Rp 8 juta). Batas kemiskinan yang dihasilkan kriteria kesejahteraan subjektif terlihat sangat tinggi, sehingga tidak dipilih karena angka ini adalah merupakan ekspektasi keluarga terhadap pendapatan. Sementara, batas kemiskinan menurut pengeluaran pangan yang dianggap paling baik dan terpilih karena lebih mampu mengklasifikasikan keluarga miskin lebih banyak dibandingkan kriteria BKKBN.

Hasil penelitian ini juga menunjukkan bahwa pendidikan kepala rumah tangga $\leq 12$ tahun (setara SLTA) dapat dimasukkan dalam kategori miskin/tidak sejahtera. Selain itu, bila dilihat dari segi umur, penelitian ini juga menghasilkan indikator kesejahteraan yakni umur < 60 tahun masih belum bisa dianggap

Vol. 1 No. 1/Januari 2008 - 26 
sejahtera oleh keluarga atau dengan kata lain sejahtera baru dirasakan bila usia kepala keluarga sudah di atas 60 tahun. Persepsi harga mengindikasikan bahwa skor < 58 masih dianggap tidak sejahtera.

Sesuai dengan keluarga yang menjadi contoh dalam penelitian ini, maka cut off kesejahteraan/kemiskinan yang telah disebutkan di atas, dapat diterapkan untuk wilayah perkotaan. Batas kemiskinan Rp 230,000.00 berdasarkan pendapatan berada di atas garis kemiskinan BPS khususnya untuk wilayah perkotaan Sumatera Utara (Rp 130,541.00) diharapkan mampu mencerminkan tingkat pendapatan minimum yang diperlukan untuk memperoleh gizi seimbang, serta memenuhi kebutuhan untuk pelayanan kesehatan, pendidikan dan kebutuhan dasar lainnya.

\section{SIMPULAN DAN SARAN}

\section{Simpulan}

1. Rata-rata pengeluaran non pangan keluarga tidak miskin enam kali lebih besar (Rp 608,700.50) dibandingkan kelompok keluarga miskin (Rp 103,925.40). Pengeluaran keluarga tidak miskin pada semua komponen non pangan, lebih tinggi dibandingkan pengeluaran keluarga tidak miskin. Rata-rata pengeluaran total keluarga tidak miskin lebih besar dibandingkan keluarga miskin. Persentase pengeluaran pangan pada keluarga miskin (56.4\%) lebih besar dibandingkan pengeluaran non pangan (43.6\%). Sebaliknya, pada keluarga tidak miskin, persentase pengeluaran pangan (33.6\%) lebih rendah dibanding pengeluaran non pangan (66.4\%) yang berbeda nyata secara statistik.

2. Hasil analisis regresi berganda menunjukkan bahwa pendidikan dan pendapatan berpengaruh nyata terhadap pengeluaran keluarga dengan nilai $r$ kuadrat sebesar $74.9 \%$.

3. Sebanyak $38.0 \%$ keluarga contoh tergolong miskin menurut kriteria BKKBN. Penggunaan indikator kemiskinan BPS hanya mampu mengklasifikasikan keluarga miskin sebesar $\quad 2.0 \%$. Berdasarkan indikator kemiskinan menurut pengeluaran pangan, sebagian besar $(62.0 \%)$ keluarga termasuk ke dalam kategori tidak miskin. Penggolongan kesejahteraan berdasarkan persepsi subjektif, diperoleh $78.0 \%$ keluarga termasuk kategori tidak sejahtera.

4. Ketiga indikator kemiskinan/kesejahteraan (BKKBN, pengeluaran pangan dan persepsi subjektif) mempunyai sensitifitas yang tinggi yakni $100.0 \%$ jika digunakan kriteria BPS sebagai gold standard. Spesifisitas tertinggi dijumpai pada kriteria BKKBN dan pengeluaran pangan yakni $63.3 \%$, dan yang paling rendah adalah kriteria persepsi subjektif (22.4\%).

5. Faktor determinan kriteria kesejahteraan BPS adalah pendidikan kepala RT. Faktor determinan kesejahteraan menurut kriteria BKKBN adalah pendapatan. Faktor determinan kriteria kesejahteraan menurut pengeluaran pangan adalah jumlah anggota RT dan pendapatan. Faktor determinan kesejahteraan menurut persepsi subjektif adalah pendidikan kepala RT, umur kepala RT, persepsi harga dan pendapatan.

\section{Saran}

1. Berdasarkan hasil penelitian ini disarankan untuk mempergunakan cut off point pendapatan sebagai garis kemiskinan sebesar Rp $230,000.00$ per kapita per bulan. Keluarga yang memiliki pendapatan di bawah Rp 230,000.00 besar kemungkinan akan merasa kurang sejahtera menurut tiga indikator. 


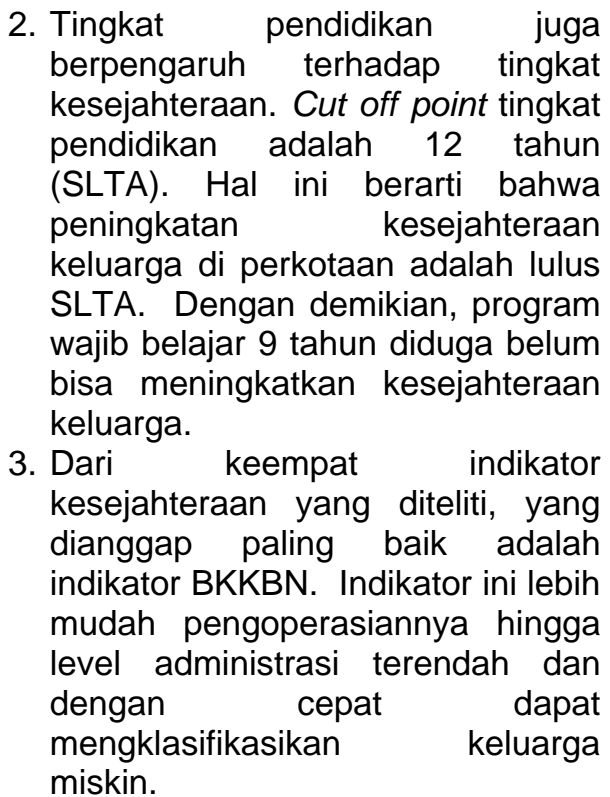

\section{DAFTAR PUSTAKA}

[BKKBN] Badan Koordinasi Keluarga Berencana Nasional. 2001. Analisa Hasil Pendataan Keluarga Tahun 2001. Bogor: BKKBN.

[BPS] Badan Pusat Statistik. 2000/2001/2003. Statistik Indonesia 2000/2001/2003. Jakarta: BPS.

2001. Indikator Kesejahteraan Rakyat Kota Medan 2001. Sumatera Utara: BPS.

Ghany, A \& D.L. Sharpe. 1997. Consumption Patterns Among Ethnic Groups in Canada.

Mathur, O.P. 1994. The State of India's Urban Poverty. Asian Development Review 12(1):32-67.

Megawangi, R, et al. 1994. Gender Perspectives in Early Childhood
Care and Development in Indonesia, The Consultative Group on Early Childhood Care and Development, Indonesia.

Raharto, Aswatini \& Romdiati, H. 2000. Identifikasi Rumah Tangga Miskin. Widya Karya Nasional Pangan dan Gizi (WKNPG) VII. Jakarta: Lembaga IImu Pengetahuan Indonesia (LIPI), Bappenas, Unicef, Deptan, Depkes, dan BPS.

Roedjito, D. 1989. Kajian Penelitian Gizi. Jakarta: Mediyatma Sarana Perkasa.

Rusli, et al. 1995. Metodologi Identifikasi Golongan dan Daerah Miskin: Suatu Tinjauan dan Alternatif. Jakarta: Gramedia Widiasarana Indonesia.

Sajogyo. 1997. Wawancara, Ukuran Garis Kemiskinan yang Telah Dipakai 20 Tahun Harus Direvisi. wwwb.tempo.co.id/ang/min/02/29/ekbis1 htm.edisi 29/02 [17 September 97].

Subagio, D., dkk. 2001. Kemiskinan di Indonesia dalam Perspektif Ekonomi: Sebuah Kajian Permodelan. Makalah Falsafah Sains Program Pascasarjana, IPB.

Sugiarto, Kelana, Herlambang, Sudjana \& Brastoro. 2000. Ekonomi Mikro Suatu Pendekatan Praktis. Jakarta: Gramedia Pustaka Utama.

Suhardjo. $\quad 1989 . \quad$ Sosio Budaya Gizi. Pusat Antar Universitas Pangan dan Gizi. IPB.

Sukirman. 1991. Dampak Pembangunan terhadap Keadaan Gizi. Orasi Penerimaan Jabatan Guru Besar Luar Biasa IImu Gizi. Fakultas Pertanian, IPB.

Susenas. 1999. Laporan Sosial Indonesia 1998. Kemiskinan, Pengangguran dan Setengah Pengangguran.

1 Staf Pengajar Universitas Negeri Medan

2 Staf Pengajar Departemen IImu Keluarga dan Konsumen, FEMA IPB

3 Staf Pengajar Departemen IImu Keluarga dan Konsumen, FEMA IPB 